\title{
WALANG GORENG SEBAGAI IKON WISATA KULINER GUNUNGKIDUL
}

\author{
Siti Halimah Agustina dan V. Indah Sri Pinasti \\ e-mail : sitiagst@gmail.com
}

\begin{abstract}
Abstrak
Penelitian ini bertujuan untuk mengetahui bagaimana walang goreng dapat menjadi ikon wisata kuliner Gunungkidul dan mengetahui apa saja dampak sosial serta ekonomi dengan adanya walang goreng sebagai ikon wisata kuliner bagi masyarakat Gunungkidul. Penelitian ini menggunakan metode penelitian kualitatif. Informan penelitian berjumlah 10 orang yang dipilih dengan teknik purposive sampling. Teknik pengumpulan data melalui wawancara dan observasi. Validitas data menggunakan triangulasi sumber data. Teknik analisis data menggunakan model interaktif Miles dan Huberman yaitu melalui pengumpulan data, reduksi data, penyajian data dan penarikan kesimpulan. Hasil penelitian menunjukkan bahwa dalam menjadikan walang goreng sebagai ikon wisata kuliner Gunungkidul dapat dilihat dari sejarah dan representasi walang goreng terhadap identitas daerah serta strategi yang dilakukan dalam menjadikan walang goreng sebagai ikon wisata kuliner Gunungkidul melalui faktor-faktor yang membentuknya. Keberadaan walang goreng sebagai ikon wisata kuliner Gunungkidul diwujudkan dengan menjadikan walang goreng sebagai atraksi wisata di Gunungkidul yang mampu memberikan dampak secara sosial dan ekonomi bagi masyarakat Gunungkidul.

Kata Kunci: Walang Goreng, Ikon, Wisata, Kuliner, Gunungkidul
\end{abstract}

\section{Abstract}

This study aims to find out how walang goreng can become an icon of Gunungkidul culinary tourism and find out what social and economy impact caused by walang goreng as the icon of Gunungkidul culinary tourism for Gunungkidul community. This study used a qualitative research methods. The research informant were 10 people who selected by purposive sampling technique. The technique of collecting data through interviews and observation. Data validity uses data source triangulation technique. The data analysis technique uses the interactive models of Miles and Huberman, namely through data collection, data reduction, data presentation, and conclusions. The result of study showed that walang goreng as the icon of Gunungkidul culinary tourism can be seen from the history and the representation of walang goreng on regional identity and the strategies in making walang goreng as the icon of Gunungkidul culinary tourism through the factors that forming it. Attracting walang goreng as the icon of Gunungkidul culinary tourism is realized by making them as a tourism attraction in Gunungkidul that can give an impact of social and economy for Gunungkidul community.

Key Words: Walang Goreng, Icon, Tourism, Culinary, Gunungkidul

\section{Pendahuluan}

Pariwisata menjadi salah satu sektor yang potensial untuk dikembangkan dan menjadi sarana dari pembangunan masyarakat. Dari segi pembangunan bangsa, sektor pariwisata memiliki 3 fungsi pokok yaitu, fungsi secara ekonomi, sosial dan budaya. Gunungkidul adalah salah satu kabupaten di Daerah Istimewa Yogyakarta yang terkenal akan pariwisatannya. Berbagai jenis pariwisata yang tersedia di Gunungkidul tidak terlepas dari potensi yang dimiliki Gunungkidul mulai dari alam, keberagaman budaya dan kearifan lokal yang terdapat dalam masyarakat Gunungkidul. Setiap daerah memiliki keunikan serta kekhasan tersendiri dalam pariwisata baik dari suku, tradisi, bahasa daerah, pakaian adat maupun dari makanan khas daerah. Salah satu bentuk keunikan dari adanya budaya yang beragam seperti 
yang disebutkan di atas adalah adanya wisata kuliner yang menyuguhkan makanan khas dari sebuah daerah. Wisata kuliner menjadi sebuah jenis wisata yang sangat banyak dampaknya bagi perkembangan sebuah daerah (Stowe \& Johnston, 2010). Berdasarkan hal tersebut, perlu dibuat sebuah usaha meningkatkan potensi ini dengan memberikan sentuhan atau dukungan untuk dapat menarik wisatawan lokal atau asing dalam menikmati kuliner asli daerah. Wisata kuliner merupakan salah satu daya tarik bagi wisatawan yang mengadakan suatu perjalanan wisata dengan tujuan untuk menikmati berbagai jenis makanan yang khas dan enak dari daerah tersebut.

Menurut Asosiasi Pariwisata Kuliner Internasional (International Culinary Tourism Association/CTA) dalam Suwantoro (2004: 46) wisata kuliner merupakan kegiatan makan dan minum yang unik dilakukan oleh setiap pelancong yang berwisata. Jargon "eating and tourism always go hand in hand" terbukti dengan semakin berkembangnya wisata kuliner baik dari tersedianya tempat kuliner ataupun dari perkembangan kuliner itu sendiri (Virna, 2007). Melalui kegiatan pariwisata, kuliner tidak hanya sebatas produk pemuas kebutuhan dasar manusia saja. Kuliner memiliki unsur budaya asli suatu daerah dapat menjadi daya tarik bagi wisatawan untuk datang mengunjungi daerah tersebut.

Wisata kuliner di Indonesia mulai terdengar gaungnya sekitar tahun 2005 akibat berbagai tayangan wisata kuliner di televisi. Hingga saat ini, wisata kuliner di Indonesia semakin menunjukkan perkembangannya. Wisata kuliner di Indonesia dengan keragaman jenisnya mempunyai pangsa pasar yang beragam dengan karakteristik yang variatif, dilihat dari status sosial, tingkat perekonomian, ataupun gaya hidup seseorang wisatawan (Virna, 2007). Merebaknya tren wisata kuliner di berbagai daerah di Indonesia menciptakan ikon-ikon kuliner khas daerah yang banyak dicari oleh wistawan. Pada tahun 2011, beberapa masakan Indonesia seperti Sate, Nasi Goreng, dan Rendang ke dalam daftar World's 50 Best Foods versi CNN dimana Rendang menduduki posisi pertama (Lazuardi, 2015). Keberadaan rendang sebagai ikon kuliner di Kota Padang merupakan strategi sekaligus dampak yang didapatkan dari adanya kegiatan pariwisata, khususnya wisata kuliner. Jenis kuliner lain yang menjadi ikon wisata kuliner di Indonesia adalah Rawon yang menjadi makanan khas dari Surabaya.

Menurut Pierce, ikon adalah hubungan antara tanda dan obyeknya atau acuan yang bersifat kemiripan. Budiman (2015) memberikan pengertian bahwa ikon adalah tanda yang memiliki kemiripan atau similaritas dengan obyeknya (dalam Marzuqi, 2015). Ikon dapat diartikan pula sebagai ciri khas daerah yang mampu melambangkan karakter dan identitas dari sebuah daerah.

Ikon dalam pariwisata merujuk pada 
tanda atau benda visual yang mampu menggambarkan hubungan antara yang dijadikan ikon dengan hal-hal yang menjadi daya tarik dalam wisata (Marzuqi, 2015). (Becken, 2005). Ikon wisata adalah asset alami atau buatan yang diterima secara luas oleh pengunjung sebagai bagian dari atraksi wisata ataupun pengalaman di tempat wisata. Dengan kata lain, ikon wisata adalah landmark yang secara langsung dapat dikenali karena mereka terkenal di kawasan pariwisata tersebut. Pembentukan ikon dalam pariwisata adalah hasil dari proses panjang yang melibatkan masyarakat sebagai pelaku usaha pariwisata, identitas daerah wisata serta wisatawan itu sendiri. Ikon wisata dapat terbentuk berkaitan dengan proses pembentukan atraksi wisata sebagai daya tarik dalam kegiatan pariwisata (Becken, 2005). Dalam pariwisata kuliner, ikon wisata adalah berupa produk kuliner yang menjadi ciri khas daerah wisata dan dikembangkan menjadi atraksi wisata.

Dalam pengembangan atraksi wisata, kuliner lokal mampu menjadi unsur yang dapat direduksi tidak sekedar sebagai pengisi perut tetapi dikemas dalam sebuah atraksi wisata. Indonesia berpotensi besar dalam wisata makanan (food tourism) karena memiliki kekayaan etnis dan budaya, yang masing-masing memiliki kuliner khas tersendiri. Untuk mengangkat kuliner lokal sebagai atraksi wisata diperlukan strategi yang komprehensif yaitu; Mengidentifikasi jenis- jenis makanan lokal yang memiliki peluang untuk dikembangkan sebagai ikon dan daya tarik wisatawan; Memetakan situasi dan kondisi (popularitas) jenis makanan; Merancang bentuk kegiatan food tourism (meliputi atraksi, event) yang diintegrasikan dengan daya tarik wisata setempat (Nurhidayati, 2013).

Makanan lokal yang menjadi identitas dari sebuah daerah merupakan cerminan budaya setempat. Melalui kegiatan wisata, makanan dapat mewakili pengalaman budaya, status, identitas budaya dan berkomunikasi (Frochot, 2003: 82). Pengembangan budaya lokal termasuk makanan lokal memiliki nilai strategis selain menciptakan atraksi wisata alternatif juga menjadi instrument untuk meningkatkan kesejahteraan masyarakat setempat.

Di tengah kegiatan pariwisata yang sedang berkembang di Gunungkidul, wisata kuliner menjadi pilihan alternatif untuk menikmati alam dan budaya yang ada di Gunungkidul. Wisata kuliner potensial untuk dikembangkan karena wisatawan yang datang biasanya tertarik untuk mencoba makanan khas daerah tersebut. Salah satu ciri produk wisata adalah tidak dapat dipindahkan, tetapi wisatawan-lah yang harus datang jika ingin menikmati produk wisata yang diproduksi, merupakan hal yang tepat untuk dijadikan dasar pengembangan wisata kuliner (Suwantoro, 2004: 48).

Seperti yang telah dijelaskan sebelumnya, kuliner lokal adalah ekspresi 
nyata dari kebudayaan suatu daerah yang dapat menjadi bahan dalam menganalisis, memahami sejarah, budaya dan kehidupan masyarakatnya. Demikian pula dengan walang goreng sebagai kuliner lokal khas Gunungkidul. Keberadaan walang goreng di tengah pariwisata kuliner di Gunungkidul dianggap mampu merepresentasikan identitas Gunungkidul.

Dalam pariwisata, identitas dapat merujuk pada norma atau produk yang khas dan menjadi ikon pariwisata daerah tersebut. Identitas dapat berisi atribut fisik, keanggotaan dalam kelompok, keyakinan, tujuan, harapan dan prinsip moral atau gaya sosial (Kellner, 2010: 317). Dalam pariwisata, identitas dapat diwujudkan melalui ikon wisata yang mampu merepresentasikan identitas daerah tersebut. Identitas tidak terbentuk secara sendiri, namun terdapat beberapa faktor yang mempengaruhi terbentuknya identitas yaitu:

a. Kreativitas

b. Ideologi Kelompok

c. Status Sosial

d. Media Massa

e. Kesenangan (Pleasure and Fun)

Pembentukan identitas dalam wisata berkaitan dengan konstruksi identitas yang terbentuk melalui perilaku atau kebiasaan sosial masyarakat di kawasan pariwisata dalam kehidupan sehari-hari yang saling mengikat antara masyarakat dengan keseharian atau keunikan mereka. Dalam wisata kuliner sendiri yang menjadi identitas adalah produk makanan. Seperti yang dikemukakan oleh Virna (2007) bahwa produk kuliner tidak hanya menampilkan makanan khas namun dapat memperluas wawasan wisatawan mengenai cara makan, gaya hidup, tradisi, kebudayaan, kesejarahan, sampai unsur geografis yang ditampilkan melalui penyajian dan cita rasa hidangan tersebut. Daerah-daerah di Indonesia memiliki kuliner khas yang tidak dimiliki oleh daerah lain dan hal tersebut menjadikan sebuah ikon dan identitas daerah yang banyak dijadikan oleh-oleh khas daerah (Virna, 2007).

Berbagai daerah yang memiliki potensi pariwisata memunculkan ikon-ikon wisata yang dianggap mampu merepresentasikan identitas daerah mereka. Penetapan sebuah ikon berkaitan dengan hal-hal khas yang ingin ditunjukkan kepada masyarakat sehingga ketika masyarakat berbicara mengenai suatu daerah atau kegiatan akan dikaitkan dengan ikon dan identitas tertentu. Dalam pariwisata kuliner, sebuah ikon wisata dapat diartikan sebagai produk kuliner yang khas dan otentik dari daerah tersebut. Salah satu kuliner unik yang saat ini menjadi andalan wisata kuliner Gunungkidul adalah olahan walang goreng yang tersedia di "Toko Oleh-Oleh Pak Gareng" dan pedagang di sepanjang kawasan Hutan Bunder.

Walang goreng merupakan salah satu produk wisata kuliner khas Gunungkidul. Masyarakat Gunungkidul sudah sejak zaman dahulu mengkonsumsi 
makanan ini. Seiring dengan perkembangan pariwisata di Gunungkidul, walang goreng dijadikan sebagai produk wisata dan menjadi bagian dari atraksi wisata kuliner di Gunungkidul.

Keberadaan walang goreng sebagai ikon wisata kuliner di Gunungkidul menjadi semakin berkembang dan memiliki dampak bagi perkembangan masyarakat. Perkembangan masyarakat dapat dilihat dari sisi ekonomi, perkembangan struktur sosial, dsb. Secara teoritis, Cohen (1984) dalam Pitana

(2009:194) mengelompokkan dampak sosial budaya pariwisata kedalam beberapa hal. Salah satunya ialah dampak sosial dan ekonomi masyarakat yang berada di kawasan pariwisata. Dampak sosial dapat dilihat dari keterkaitan dan keterlibatan antara masyarakat setempat dengan masyarakat yang lebih luas, termasuk tingkat otonomi atau ketergantungannya. Selain itu dapat dilihat pula pada hubungan interpersonal antara anggota masyarakat. Sedangkan, dampak ekonomi dapat dilihat dari pengaruh pariwisata terhadap kehidupan dan kesejahteraan masyarakat yang tidak bisa dilepaskan dari peningkatan ekonomi masyarakat.

Pengembangan pariwisata suatu daerah akan memberikan dampak positif maupun dampak negatif. Dampak tersebut akan berpengaruh terhadap kondisi fisik maupun kehidupan sosial ekonomi penduduk yang berada di sekitar obyek wisata (Purnamasari, 2011).

\section{Metode}

Metode penelitian yang digunakan dalam penelitian ini mengunakan metode kualitatif dengan paparan deskriptif analisis. Teknik pengumpulan data menggunakan wawancara dan observasi. Penentuan informan menggunakan purposive sampling dengan berbagai kriteria yang telah ditentukan untuk setiap kelompok informan. Adapun informan dalam penelitian ini terdiri dari pemilik toko, pedagang, masyarakat sekitar yang terlibat, Dinas Pariwisata Gunungkidul dan wisatawan yang berada di lokasi penelitian. Validitas data yang digunakan adalah teknik triangulasi sumber data dan menggunakan teknik analisis data Miles dan Huberman.

\section{Hasil dan Pembahasan}

\section{Perkembangan Wisata Kuliner di Gunungkidul}

Kabupaten Gunungkidul adalah salah satu kabupaten yang berada di Daerah Istimewa Yogyakarta. Secara regional wilayah kabupaten Gunungkidul merupakan bagian dari zona fisiografi pegunungan selatan Jawa Timur. Kabupaten Gunungkidul terbagi dalam 6 kawasan startegis pariwisata yang menjadikan daya tarik wisata destinasi wisata di Gunungkidul sangat beragam mul dari wisata alam, wisata budaya, wisata berbasis buatan, wisata pendidikan, desa wisata dan desa budaya, cinderamata dan wisata kuliner. Berbagai jenis dan daya tarik wisata tersebut 
merupakan potensi yang mampu produk wisata kuliner. Dalam mendatangkan wisatawan baik domestik menjadikan walang goreng maupun mancanegara ke Gunungkidul. Jumlah wisatawan yang berkunjung ke Gunungkidul meningkat sejak tahun 2012 hingga tahun 2018.

Wisata kuliner di Gunungkidul mengalami perkembangan seiring dengan berkembangnya pariwisata di Gunungkidul. Wisata kuliner di Gunungkidul menjadi alternatif saat melakukan kegiatan pariwisata di Gunungkidul. Hal ini dapat terlihat dari berkembangnya banyak rumah makan, toko oleh-oleh khas dan para pedagang makanan di kawasan pariwisata di Gunungkidul. Beragam jenis wisata kuliner di Gunungkidul, secara umum merupakan makanan yang berasal dari bahan baku lokal. Setiap jenis makanan memiliki rasa dan bahan baku yang berbeda Beragam jenis tersebut antara lain sego abang, gathot, tiwul, pathilo, aneka olahan ikan, peyek jingkeng, keripik rumput laut, keripik singkong, walang goreng dsb. Berbagai kuliner tersebut menjadi produk wisata kuliner yang banyak di minati wisatawan baik lokal maupun mancanegara.

2. Walang Goreng sebagai Produk dan Ikon Wisata Kuliner Gunungkidul

a. Sejarah Kuliner Walang Goreng sebagai Produk Wisata Kuliner

Salah satu strategi kuliner lokal untuk bertahan adalah dengan mereduksi makanan lokal tidak sekedar sebagai pengisi perut tetapi mengemasnya menjadi sebagai produk wisata kuliner dapat terlihat dari sejarahnya, yaitu:

1) Belalang dianggap sebagai hama penganggu tanaman. Belalang goreng selanjutnya disebut dengan walang goreng termasuk dalam golongan kuliner ekstrem karena kuliner ini berasal dari serangga jenis belalang yang banyak di temukan di Gunungkidul. Pada awalnya belalang dianggap sebagai hama bagi tanaman terutama bagi dedaunan dan sering kali merugikan atau menganggu petani sehingga timbul inisiatif dan kreativitas dari masyarakat untuk mengolah belalang menjadi kuliner untuk dikonsumsi sebagai makanan.

2) Kebiasaan masyarakat yang telah mengkonsumsi walang goreng sejak dahulu. Kebiasaan masyarakat dalam mengkonsumsi walang goreng tidak terlepas dari kondisi wilayah Gunungkidul yang banyak ditumbuhi pepohonan dan juga banyak lahan pertanian yang merupakan habitat belalang itu sendiri. Masyarakat Gunungkidul telah sejak dahulu mengkonsumsi 
belalang goreng bahkan sebelum berkembang menjadi produk wisata kuliner. Bahkan, pada zaman dulu, belalang dijadikan makanan pengganti daging bagi mereka yang kurang mampu membeli daging.

3) Perkembangan pariwisata di Gunungkidul. Potensi pariwisata yang ada di Gunungkidul mendorong kedatangan wisatawan untuk menikmati berbagai jenis pariwisata yang ada di Gunungkidul termasuk wisata kuliner. Walang goreng hadir sebagai salah satu produk wisata kuliner yang banyak diminati oleh wisatawan baik karena keunikan dan ke khasan kuliner tersebut. Adanya pariwisata yang berkembang di Gunungkidul juga menjadi sarana legitimasi bagi kuliner walang goreng sebagai produk wisata kuliner di Gunungkidul. Hal tersebut juga berkaitan dengan kegiatan pariwisata, dimana wisatawan tidak akan terlepas dari makanan.

b. Representasi Identitas Daerah melalui Walang Goreng sebagai Ikon Wisata Kuliner Gunungkidul

$$
\text { MacCannell }
$$

memberikan gambaran bahwa produk kuliner tidak hanya menampilkan makanan khas yang terwujud dalam ikon kuliner akan tetapi dapat berkembang menjadi suatu media interpretasi yang memperluas wawasan wisatawan terhadap identitas dan karakter daerah wisata (dikutip dari Virna, 2007). Dalam pariwisata, identitas merujuk pada norma atau produk yang khas dan menjadi identitas dari daerah wisata tersebut. Melalui produk atau norma tersebut, gambaran sebuah daerah dapat diketahui baik keadaan alam maupun sosial masyarakat. Dengan adanya kuliner walang goreng ini, identitas Gunungkidul sebagai daerah pegunungan dengan hutan dan lahan pertanian yang luas tergambarkan melalui kuliner walang goreng tersebut. Selain itu, diketahui bahwa sejarah dijadikannya walang goreng menjadi produk kuliner khas Gunungkidul tidak terlepas dari luasnya lahan pertanian serta mata pencaharian masyarakat sebagai petani yang mampu mengolah dan memanfaatkan alam untuk kebutuhan mereka sendiri.

Melalui makanan atau kuliner kita dapat mengkomunikasikan hubungan, ideologi, nilai sosial dan juga identitas masyarakat suatu daerah (Virna, 2007). Walang goreng memiliki nilai sosial historis bagi masyarakat Gunungkidul yaitu sejak zaman dahulu masyarakat mengolah dan mengkonsumsi belalang goreng untuk memenuhi kebutuhan pangan mereka. Selain 
itu, hal ini juga terkait dengan karakter sederhana yang dimiliki masyarakat desa dimana bertani menjadi aktivitas utama untuk mencukupi kebutuhan hidup. Dijadikannya walang goreng sebagai ikon wisata kuliner merupakan hasil ciptaan dan kebiasaan masyarakat Gunungkidul yang telah sejak dahulu mengolah belalang menjadi kuliner. Kegiatan pariwisata dimana didalamya terdapat interaksi antara wisatawan dengan masyarakat Gunungkidul menjadi sarana legitimasi atau pengakuan mengenai kuliner walang goreng sebagai ikon wisata kuliner Gunungkidul melalui proses sosialiasi yang terjadi. Proses sosialisasi dapat terjadi karena struktur sosial masyarakat Gunungkidul yang dinamis sesuai dengan semboyan HANDAYANI dimana salah satu makna dalam semboyan tersebut adalah Dinamis yang berarti masyarakat harus mampu untuk beradaptasi dengan lingkungan dan tuntutan sehingga keberhasilan (kesejahteraan) masyarakat akan mudah tercapai (gunungkidulkab.go.id, 2019). Hal tersebut terwujud dalam menjadikan walang goreng dan kuliner lokal lain sebagai produk wisata kuliner sehingga tidak hanya sekedar menjadi makanan lokal saja namun sebagai produk makanan atau kuliner yang dikomersilkan melalui pariwisata.

Berdasarkan uraian diatas, dapat menunjukkan bahwa walang goreng memiliki peran dan fungsi bagi masyarakat Gunungkidul karena mampu merepresentasikan keadaan alam dan sosial masyarakat Gunungkidul.

c. Strategi Menjadikan Walang Goreng sebagai Ikon Wisata Kuliner Gunungkidul

Pada wisata kuliner di Gunungkidul, identitas sosial yang dimiliki disimbolkan melalui atribut fisik yang menjadi ikon wisata yaitu berupa walang goreng. Sehingga apabila masyarakat khususnya wisatawan yang datang ke Gunungkidul membicarakan kuliner Gunungkidul akan dikaitkan dan identik dengan walang goreng. Adanya walang goreng sebagai ikon wisata kuliner Gunungkidul tidak terbentuk secara sendiri, namun terdapat beberapa faktor yang mempengaruhinya. Faktorfaktor pembentuk walang goreng sebagai ikon wisata kuliner Gunungkidul adalah sebagai berikut:

1) Kreativitas dalam wisata kuliner di Gunungkidul ditunjukkan dengan kemampuan masyarakat Gunungkidul yang mampu mengolah serangga 
menjadi makanan yang dapat

dikonsumsi. Selain itu kreativitas dalam wisata kuliner di Gunungkidul juga ditunjukkan melalui cara penjualan dan penyajian walang goreng oleh para pedagang di kawasan sepanjang jalan kawasan Hutan Bunder dengan cara dadakan atau langsung dimasak ditempat. Cara tersebut merupakan bentuk kreativitas masyarakat dalam menjadikan walang goreng sebagai produk sekaligus ikon wisata kuliner Gunungkidul.

2) Ideologi kelompok masyarakat Gunungkidul dalam kegiatan pariwisata bersumber pada Sapta Pesona Pariwisata yang menjadi landasan dalam mengembangkan pariwisata Gunungkidul (Dinas Pariwisata Gunungkidul, 2017). Unsur ke tujuh yaitu berupa kenangan (cinderarasa) menjadi sumber ideologi masyarakat Gunungkidul dalam kegiatan wisata kuliner yaitu dengan menyediakan walang goreng sebagai produk cinderarasa sehingga menjadikan wisata kuliner di Gunungkidul identik dengan kuliner walang goreng.

3) Status social Gunungkidul dikenal sebagai daerah dengan potensi alam yang melimpah dimana terdapat lahan pertanian dan hutan yang luas sebagai habitat asli dari belalang sebagai bahan baku walang goreng. Selanjutnya dengan adanya walang goreng sebagai kuliner khas Gunungkidul berkaitan dengan banyaknya masyarakat yang berstatus sebagai pedagang dan pengusaha kuliner walang goreng. Keberadaan para penyedia kuliner khas tersebut yang menjadi fakor pendorong terbentuknya ikon kuliner Gunungkidul.

4) Media massa yang yang terlibat dalam membentuk walang goreng sebagai ikon wisata kuliner di Gunungkidul antara lain melalui sosial media seperti instagram, facebook, twitter, blog dan website. Selain media internet, juga menggunakan media seperti radio dan surat kabar. Berbagai jenis media tersebut digunakan sebagai sarana untuk mengenalkan walang goreng sebagai ikon wisata kuliner Gunungkidul. Sehingga ketika masyarakat berbicara mengenai wisata kuliner di Gunungkidul identik dengan kuliner walang goreng nya.

5) Kesenangan (Pleasure and 


Fun). Pariwisata dapat
digolongkan menjadi suatu
kegiatan yang tidak terlepas
dari unsur kesenangan.
Walang goreng menjadi
makanan lokal yang memenuhi
tujuan dari kegiatan wisata
kuliner di Gunungkidul yaitu
terpenuhinya unsur
kesenangan dalam mencicipi
makanan lokal setempat bagi
wisatawan yang berkunjung.

Selanjutnya dengan berbagai faktor yang membentuk walang goreng sebagai ikon wisata kuliner Gunungkidul tersebut, diwujudkan berbagai strategi yang dilakukan dalam menjadikan dan mempertahankan walang goreng sebagai ikon wisata kuliner Gunungkidul sebagai berikut:

a. Mengikuti pameran di berbagai daerah Melalui pameran, walang goreng diperkenalkan kepada masyarakat yang lebih luas sebagai produk kuliner yang khas dari Gunungkidul. Berdasarkan hasil wawancara dengan Dinas Pariwisata diketahui bahwa peminat produk-produk olahan Gunungkidul termasuk kulinernya sangat banyak di luar Jawa.

Selain itu, berdasarkan hasil wawancara dengan dinas Pariwisata diketahui bahwa ada upaya dari Pemerintah Kabupaten Gunungkidul untuk menjadikan belalang sebagai identitas daerah Gunungkidul yang di tuangkan dalam Surat Keputusan Bupati Gunungkidul Nomor 176/KPTS/2013 mengenai kebijakan pemakaian seragam batik motif Walang Jati Kencono bagi para pegawai di lingkup Kabupaten Gunungkidul dan juga bagi anak sekolah.

b. Melakukan promosi wisata melalui online dan offline

Untuk mendatangkan wisatawan yang lebih banyak, promosi pariwisata di Gunungkidul dilakukan secara daring (online) maupun secara langsung (offline). Terkait dengan promosi belalang goreng sebagai kuliner khas Gunungkidul dengan cara online antara lain melalui media sosial baik berupa instagram, twitter, facebook, youtube dan melalui website Dinas Pariwisata sendiri.

Sedangkan, untuk mengenalkan walang goreng secara langsung selain melalui pameran, juga melalui adanya travel-dialog yang mendatangkan berbagai pihak seperti kepala sekolah, instansi pemerintahan, travel agent dan biro perjalanan wisata. Selain itu, promosi dalam bentuk benda berupa banner, $\mathrm{x}$ banner, leaflet, poster di tempat-tempat wisata di Gunungkidul.

$$
\text { Dengan sosialisasi tersebut }
$$
membuat masyarakat termasuk wisatawan mampu memaknai walang goreng sebagai ikon kuliner Gunungkidul karena masyarakat terbiasa menghadapi keberadaan 
walang goreng sebagai bagian dari kuliner Gunungkidul.

C. Menerapkan strategi penjualan online

Dalam penjualan online, para pedagang memanfaatkan marketplace seperti Bukalapak, Shopee dan juga Facebook dan mengirimkan walang goreng melalui jasa pengiriman. Hasil penelitian menunjukkan bahwa peminat kuliner walang goreng tidak hanya masyarakat dalam negeri, namun juga mereka yang berada di luar negeri. Melalui penjualan online ini selain dapat memberikan keuntungan lebih secara ekonomi juga dapat menjadikan walang goreng semakin populer dan semakin dikenal luas sebagai ikon dari kuliner Gunungkidul.

d. Bekerja sama dengan travel agent, biro perjalanan

Dalam membuat walang goreng menjadi produk yang diminati wisatawan, pengusaha, pedagang dan bahkan Dinas Pariwisata melakukan kerjasama dengan berbagai travel agent dan biro perjalanan agar wisatawan yang berkunjung ke Gunungkidul diarahkan pada sentrasentra kuliner khas seperti di toko oleholeh, kawasan pedagang ataupun restoran yang menawarkan makanan lokal sebagai menu utamanya termasuk walang goreng sebagai produk kuliner unggulan dan khas Gunungkidul. Dengan adanya kerjasama ini, selain bersifat mutualism juga secara langsung dapat mengenalkan belalang goreng sebagai ikon wisata kuliner di Gunungkidul.

e. Mengemas dalam potensi desa wisata dan pasar makanan tradisional (Pasar Digital dan Pasar Ekologis)

Berdasarkan hasil wawancara dengan Dinas Pariwisata, terdapat desa wisata yang terkenal akan potensi kuliner khususnya walang goreng yaitu di Nglanggeran, Patuk, Gunungkidul. Melalui desa wisata tersebut, wisatawan yang datang diperkenalkan dengan kuliner walang goreng yang identik dengan Gunungkidul. Selain melalui desa wisata, pemerintah dan masyarakat juga melakukan inovasi dengan membuka beberapa pasar makanan tradisional baik melalui pasar digital (Pasar Telaga Jonge, Pasar Digital Nginggrong) dan pasar ekologis (Pasar Argowijil). Pasar tersebut sengaja dibuka dengan tujuan untuk melestarikan dan mengangkat berbagai jenis makanan tradisional atau kuliner lokal khas Gunungkidul kepada masyarakat dan juga wisatawan yang datang. Termasuk di dalamnya kuliner walang goreng yang banyak diminati oleh masyarakat dan juga wisatawan.

Berbagai strategi yang dilakukan dalam menjadikan walang goreng sebagai ikon wisata kuliner Gunungkidul diatas merupakan upaya dalam menjadikan kuliner sebagai sebuah atraksi wisata. Kardigantara (2008) menjelaskan bahwa makanan dan minuman di sebuah wilayah dapat 
menjadi sebuah potensi atraksi wisata yang dapat menarik minat wisatawan. Dalam menjadikan walang goreng sebagai atraksi wisata kuliner di Gunungkidul diperlukan strategi atraksi wisata sebagai berikut:

Pertama, dengan menyediakan walang goreng sebagai jenis makanan okal yang berpeluang untuk dikembangkan sebagai ikon dan daya tarik wistatawan. Walang goreng merupakan kuliner lokal yang potensial dikembangkan dikarenakan memiliki nilai sejarah bagi masyarakat Gunungkidul serta dapat menggambarkan keadaan alam daerah Gunungkidul.

Kedua, bekaitan dengan perkembangan walang goreng menjadi produk wisata kuliner yaitu popularitas walang goreng di Gunungkidul sendiri yang banyak tersedia di toko oleh-oleh, di restoran, depot atau warung dan bahkan di tempat-tempat wisata di Gunungkidul. Selain itu, dengan banyaknya pedagang walang goreng di sepanjang jalan raya Gunungkidul menjadi salah satu daya tarik yang menjadikan walang goreng sebagai atraksi wisata kuliner,

Ketiga, tipologi dari wisata kuliner sendiri yang mudah diintegrasikan dengan wisata lain seperti wisata alam dan buatan di Gunungkidul yang banyak didatangi wisatawan. Selain itu, bentuk dari kegiatan food tourism terhadap walang goreng Gunungkidul yang banyak disediakan sebagai oleholeh khas atau sebagai menu makanan di restoran serta diintegrasikannya walang goreng dengan daya tarik wisata setempat seperti Desa Wisata di Nglanggeran.

3. Dampak Sosial dan Ekonomi adanya Walang Goreng sebagai Produk dan Ikon Wisata Kuliner Gunungkidul bagi Masyarakat

a. Dampak Sosial

1) Meningkatkan Solidaritas dalam Mengembangkan Pariwisata. Adanya pariwisata yang berkembang di Gunungkidul secara langsung mampu meningkatkan solidaritas masyarakat atas pengelolaan pariwisata hingga pemasaran dan produk pariwisata itu sendiri. Dalam wisata kuliner sendiri, solidaritas yang terbentuk dapat dilihat dari kerjasama yang dilakukan antar sektor untuk mengembangkan pariwisata termasuk mengembangkan produk kuliner sehingga mampu memberikan manfaat secara ekonomi dan sosial.

2) Meningkatkan Kebanggan sebagai Masyarakat Gunungkidul. Dengan adanya pariwisata termasuk keberadaan walang goreng dalam wisata kuliner di Gunungkidul, mampu membangkitkan kesadaran masyarakat akan potensi mereka 
sebagai obyek dan subyek pariwisata yang akan menimbulkan kebanggan pada mereka. Kebanggan mereka diwujudkan dalam berbagai bentuk salah satunya adalah dengan ikut mempopulerkan dan mengembangkan kuliner lokal termasuk walang goreng dengan menyediakan produk walang goreng dan mempopulerkan melalui media sosial mereka. Kebanggan yang timbul juga didapatkan pula dari banyaknya wisatawan yang berkunjung ke Gunungkidul dan membeli produk kuliner lokal yang ada, terutama wisatawan dan masyarakat dari luar Gunungkidul.

3) Memberi Label Gunungkidul sebagai Daerah Wisata Kuliner Ekstrem. Sebagai daerah yang memiliki potensi wisata kuliner walang goreng yang berasal dari serangga atau bahan yang tidak lazim, menjadikan Gunungkidul dikenal sebagai daerah dengan kuliner ekstrem. Anggapan tersebut merupakan label yang melekat pada daerah Gunungkidul karena keberadaan kuliner walang goreng yang berasal dari serangga dan dianggap hewan ekstrem.

b. Dampak Ekonomi

1) Membuka Mata Pencaharian bagi Masyarakat. Melalui pariwisata, masyarakat mampu mendapatkan mata pencaharaian yang akan berdampak pada kesejahteraan mereka. Dalam kaitannya dengan wisata kuliner, masyarakat mampu menjadi penyedia produk-produk makanan, supplier bahan makanan, pengelola toko, dll. Bagi para pemuda, pariwisata juga berdampak pada berkurangnya keinginan untuk merantau dan meninggalkan kampung halaman dengan terbukanya mata pencaharian seperti admin penjualan online, koordinator keamanan dan parkir dan bahkan bagian pengemasan produk.

2) Memberi Nilai Tambah dan Pengetahuan Baru dalam Pengembangan Kuliner Lokal. Dengan adanya kegiatan pariwisata di Gunungkidul secara tidak langsung memberikan peluang bagi kuliner lokal untuk dikembangkan menjadi produk kuliner yang mampu menarik wisatawan dan memberi nilai tambah secara ekonomi dan sosial budaya. Dalam proses menjadikan makanan lokal menjadi produk wisata kuliner tentu masyarakat banyak yang mendapatkan pengetahuan baru seperti bagaimana cara 
melakukan pengemasan produk, promosi dan pemasaran produk serta pengetahuan untuk melakukan inovasi produk itu sendiri.

3) Menciptakan Pasar bagi Masyarakat dalam Industri Kuliner dan Jasa Wisata. Dalam penelitian ini, diketahui bahwa dengan adanya pariwisata memberikan kesempatan bagi beberapa sektor usaha masyarakat untuk berkembang dalam industri tersebut yaitu sektor usaha kuliner dan jasa transportasi wisata. Dengan adanya walang goreng menjadi produk wisata kuliner Gunungkidul mampu mendorong industri makanan lokal lain untuk berkembang. Dengan melakukan kerjasama dengan berbagai travel agent dan biro perjalanan, para pengusaha kuliner mampu meningkatkan penjualan sekaligus memberi keuntungan bagi para pelaku usaha jasa transportasi. Berdasarkan hasil wawancara diketahi bahwa bekerja sama dengan biro perjalanan dan agen travel dapat memberikan keuntungan yang lebih besar secara ekonomi bagi pemilik usaha produk kuliner dan juga jasa transportasi.
4) Menimbulkan Persaingan antar Pedagang. Munculnya banyak pedagang yang menyediakan walang goreng sebagai produk wisata kuliner menimbulkan persaingan antara mereka. Persaingan yang timbul terdapat pada permasalahan ketersediaan bahan baku dan persaingan dalam harga jual belalang goreng. Ketika musim permintaan yang tinggi pedagang saling bersaing mendapatkan bahan baku. Untuk mencukupi kebutuhan tersebut, para pedagang banyak mendatangkan belalang dari luar wilayah Gunungkidul seperti Kebumen dan Wonogiri yang membuat harga belalang menjadi lebih mahal sehingga ketika diolah menjadi makanan pun harganya menjadi lebih tinggi.

\section{Simpulan}

Hasil penelitian Walang Goreng sebagai Ikon Wisata Kuliner Gunungkidul menunjukkan bahwa terdapat nilai historis atau sejarah mengenai bagaimana belalang goreng atau walang goreng menjadi produk wisata kuliner Gunungkidul.

Walang goreng mampu merepresentasikan identitas daerah yang dimiliki Gunungkidul antara lain keadaan alam dan sosial masyarakat Gunungkidul. 
Dalam menjadikan walang goreng sebagai ikon wisata kuliner Gunungkidul, terdapat beberapa faktor pendorong yang membentuk walang goreng menjadi ikon wisata kuliner di Gunungkidul yaitu kreativitas, ideologi kelompok, status sosial, adanya pengaruh media massa dan faktor kesenangan yaitu berkaitan tujuan dari kegiatan pariwisata itu sendiri yaitu untuk kesenangan (pleasure).

Upaya dalam menjadikan walang goreng sebagai atraksi wisata kuliner di Gunungkidul terwujud dalam berbagai strategi yaitu; mengikuti pameran di berbagai daerah di Indonesia; melakukan promosi parriwisata secara online (daring) dan juga offline; melakukan penjualan secara online melalui berbagai market place seperti Bukalapak, Shopee dan juga Facebook. Selanjutnya melakukan kerjasama dengan travel agent dan biro perjalanan dan mengemas walang goreng dalam potensi desa wisata dan menyediakan berbagai pasar makanan tradisional yang ada di Gunungkidul. Adapun strategi dalam menjadikan walang goreng sebagai ikon kuliner Gunungkidul dengan mempopulerkan melalui berbagai media, menjaga ketersediaan walang goreng, merancang bentuk food tourism walang goreng sebagai oleh-oleh dan mengintegrasikan dengan wisata yang lain.

Keberadaan walang goreng sebagai ikon wisata kuliner Gunungkidul memberikan dampak sosial dan ekonomi bagi masyarakat. Dampak sosial tersebut antara lain; meningkatkan solidaritas dalam mengembangkan pariwisata, meningkatkan kebanggaan masyarakat Gunungkidul dan memberikan label Gunungkidul sebagai daerah kuliner ekstrem. Sedangkan secara ekonomi dampak tersebut antara lain membuka mata pencaharian bagi masyarakat; memberi nilai tambah pada kuliner lokal dan pengetahuan baru terkait pengembangan kuliner lokal; menciptakan pasar bagi masyarakat dalam industri kuliner dan jasa wisata, serta menimbulkan persaingan antar pedagang.

\section{Ucapan Terima Kasih}

Terima kasih disampaikan kepada semua pihak yang terlibat dalam penelitian ini sehingga terlaksana dengan baik dan tim redaksi Jurnal Pendidikan Sosiologi Fakultas IImu Sosial UNY yang telah mempublikasikan penelitian ini.

\section{Daftar Pustaka}

Becken, S. (2005, June). The Role of Tourist Icon For Sustainable Tourism. Journal of Vacation Marketing, 11.

Frochot, I. (2003). An analysis of regional positioning and its associated food images in French Tourism Regional Tourism Brochures. Wine, Food, and Tourism Marketing.

Herdiansyah, H. (2015). Metodologi Penelitian Kualitatif untuk IImu-ilmu Sosial. Jakarta: Salemba Humanika

Lazuardi, M (2015). Rencana Pengembangan Kuliner Nasional 2015-2019 Kementrian Pariwisata dan Ekonomi Kreatif. Jakarta: PT. Republik Solusi.

Marzuqi, A. (2015). Penciptaan Motif Batik sebagai Ikon Kabupaten Lumajang. Jurnal Desain 
Komunikasi Visual Stikom

Surabaya, 4(1).

Nurhidayati, S. E. (2015). Kuliner Lokal sebagai Sumber Daya Wisata di Era Global.

Pitana, I. d. (2009). Sosiologi Pariwisata. Yogyakarta: CV Andi Offset.

Purnamasari, A. M. (2011, April). Pengembangan Masyarakat Untuk Pariwisata di Kampung Wisata Toddabojo Sulawesi Selatan. Perencanaan Wilayah dan Kota, 22.

Stowe, L. \&. (2010). Throw your napkin on the floor: Authenticity, culinary tourism, and a pedagogy of the senses. Australian Journal of Adult Learning, Number 3, 52.

Sugiyono. (2013). Memahami Penelitian Kualitatif. Bandung: Alfabeta.

Suwantoro, G. (2004). Dasar-dasar Pariwisata. Yogyakarta: Penerbit Andi.

Virna, N. (2007, Maret). Wisata Kuliner Bukan Sekedar Pemuas Nafsu Perut. Warta Pariwisata, 9. 